\title{
The first record of Calomys hummelincki (Rodentia: Sigmodontinae) from the Lavrados of northern Brazil
}

\author{
Marcus Vinicius Brandão*1, Yolanda Oliveira Salgueiro and Jorge Salazar-Bravo² \\ ${ }^{1}$ Programa de Pós-Graduação em Diversidade Biológica e Conservação, Universidade Federal de São Carlos, Campus Sorocaba. \\ Rodovia João Leme dos Santos, Km 110 - SP-264. CEP: 18052-780, Sorocaba. Sao Paulo, Brasil. Email: puerabio@gmail.com \\ (MVB), yosalgueiro@gmail.com (YOS). \\ ${ }^{2}$ Department of Biological Sciences, Texas Tech University, TX 79409, Lubbock. Texas, United States. Email: j.salazar-bravo@ttu.edu (JSB). \\ * Corresponding author
}

The South American genus Calomys exhibits a disjunct distribution with most species inhabiting grasslands, savannas, and forest edges from ca. latitude $8^{\circ} \mathrm{S}$ in the highlands of Peru and the Caatinga of Brazil to ca. latitude $16^{\circ} \mathrm{S}$ in central Bolivia, and from there south into Argentine Patagonia. Only a single species (Calomys hummelincki) occurs in open habitats in northern South America. We report the first known specimen of Calomys hummelincki for Brazil. The specimen is deposited in the mammal collection of Museu de Zoologia da Universidade de São Paulo, São Paulo. It is a young adult female with two embryos collected on 13 March 1989 by C. M. Carvalho at Fazenda Salvamento, Roraima state, during a herpetofaunal survey. The specimen shares qualitative and quantitative characters with specimens from Venezuela and Curaçao, but also differs substantially in others. The record presented herein extends the known range of the species about $630 \mathrm{~km}$ southeastward from the nearest previous record (in Venezuela, Estado Bolívar, Sipao). This new record was obtained in a locality representative of the savannas of the Rio Branco - Rupununi region that supports a poorly known, but distinctive mammalian fauna. This entire eco-region represents a piece of the biogeographic puzzle resulting from the climate-dependent vegetation shifts that dominated the Quaternary of South America. This new record highlights the need to investigate and protect the biodiversity of the Rio Branco-Rupununi savannas.

El género Sudamericano Calomys presenta una distribución discontinua, con la mayoría de sus especies presentes en los pastizales, sabanas y bordes del bosque desde $8^{\circ} \mathrm{S}$ latitud S en el altiplano de Perú y la Caatinga de Brasil hasta lat $16^{\circ} \mathrm{S}$ en el centro de Bolivia y desde allí hacia el sur, hacia la Patagonia Argentina. En este trabajo presentamos el primer registro de Calomys hummelincki para Brasil, basado en un espécimen que se encuentra depositado en la colección de mamíferos del Museo de Zoología de la Universidade de São Paulo, São Paulo. Específicamente, se trata de una hembra adulta joven con dos embriones y que fue atrapada el 13 de marzo de 1989 por C. M. Carvalho en la Fazenda Salvamento, en el estado de Roraima, durante un levantamiento de herpetofauna. Este espécimen comparte caracteres métricos y cualitativos con individuos de la misma especie y de poblaciones en Venezuela y Curaçao, aunque al mismo tiempo, difiere substancialmente en otros. El registro presentado en este trabajo extiende en alrededor de $630 \mathrm{~km}$ SE la distribución de la especie desde el registro más cercano (Venezuela, Estado Bolívar, Sipao). El registro aquí reportado proviene del sistema de sabanas denominadas del Río Branco-Rupununi, un ecosistema que contiene una fauna de mamíferos única y poco conocida. Este ecosistema representa una pieza importante en el rompecabezas biogeográfico que resultó de los cambios de vegetación que dominaron el Cuaternario de Sudamérica. Se destaca la necesidad de estudiar y proteger la biodiversidad de las sabanas Rio Branco-Rupununi.

Key words: Cerrado enclaves; Hummelinck's vesper mouse; Neotropical savannas; range extension.

(C) 2017 Asociación Mexicana de Mastozoología, www.mastozoologiamexicana.org

\section{Introduction}

Species of the genus Calomys Waterhouse, 1837 are small, mostly granivorous, rodents of the tribe Phyllotini. Despite being broadly distributed throughout open vegetation formations in South America and on islands off Venezuela, the genus remains poorly known. According to the most recent taxonomic account (Salazar-Bravo 2015), Calomys is composed of the following species: C. boliviae (Thomas 1901), C. callidus (Thomas 1916), C. callosus (Rengger 1830), C. cerqueirai Bonvicino, Oliveira and Gentile 2010, C. expulsus (Lund 1841); C. hummelincki (Husson 1960), C. laucha (Fischer 1914), C. lepidus (Thomas 1884), C. musculinus (Thomas 1913), C. sorellus (Thomas 1900), C. tener (Winge 1837), C. tocantinsi Bonvicino, Lima and Almeida 2003, C. venustus (Thomas 1894). In addition, at least three new species have been described in the last couple of years (Zeballos et al. 2014; Gurgel-Filho et al. 2015) and two more were resurrected from under the synonymy of
C. sorellus (Zeballos et al. 2014), bringing the overall total to 18 currently recognized species.

The genus has a disjunct distribution with most species inhabiting grasslands, savannas, and forest edges from ca. latitude $8^{\circ} \mathrm{S}$ in the highlands of Peru and the Caatinga of Brazil to ca. latitude $16^{\circ} \mathrm{S}$ in central Bolivia, and from there south into Argentine Patagonia (Salazar-Bravo 2015). One species (C. hummelincki) occurs in grasslands and open habitat formations in northern South America (Colombia and Venezuela) and on the Netherland Antillean islands of Curaçao and Aruba (Martino et al. 2002; Salazar-Bravo 2015). Currently, eight species of Calomys are thought to occur in Brazil: C. callidus, C. callosus, C. cerqueirai, C. expulsus, C. laucha, C. tener, C. tocantinsi, and C. mattevii (see Paglia et al. 2012; Gurgel-Filho et al. 2015).

Herein we report the first record of Hummelinck's vesper mouse ( $C$. hummelincki) from Brazil, based on a specimen 
obtained in an enclave of dry tropical savanna surrounded by rain forest in the state of Roraima.

\section{Methods}

The new specimen consists of a skin and skull (Figure 1) deposited in the mammal collections of Museu de Zoologia da Universidade de São Paulo (MZUSP 25729), São Paulo, Estado de São Paulo, Brazil. It is a young adult female (toothwear age class 3, sensu Voss 1991) collected on March 13, 1989 by C. M. Carvalho at Fazenda Salvamento, Estado de Roraima, Brazil. The specimen label indicates two embryos (preserved as MZUSP 25730).

According to C. M. Carvalho (2002), the MZUSP and Instituto Nacional de Pesquisa da Amazônia (INPA) made important expeditions to Roraima state between the years 1986 and 1991. Although the main effort was concentrated on herpetofauna, occasionally other groups were collected as well. Vanzolini and Carvalho (1991) described Fazenda Salvamento as a small cattle ranch located on the right bank of the Uraricoera River in northern Roraima state, Brazil $\left(3.333^{\circ} \mathrm{S},-61.400^{\circ} \mathrm{W}\right)$.

The collection site is within an area locally known as "lavrado", a local term used for the savannas that occur in the general area and that form part of the Rio Branco-Rupununi bioregion (see Voss 1991: figure 38). The topography of the region is dominated by interconnected streams ("igarapés")

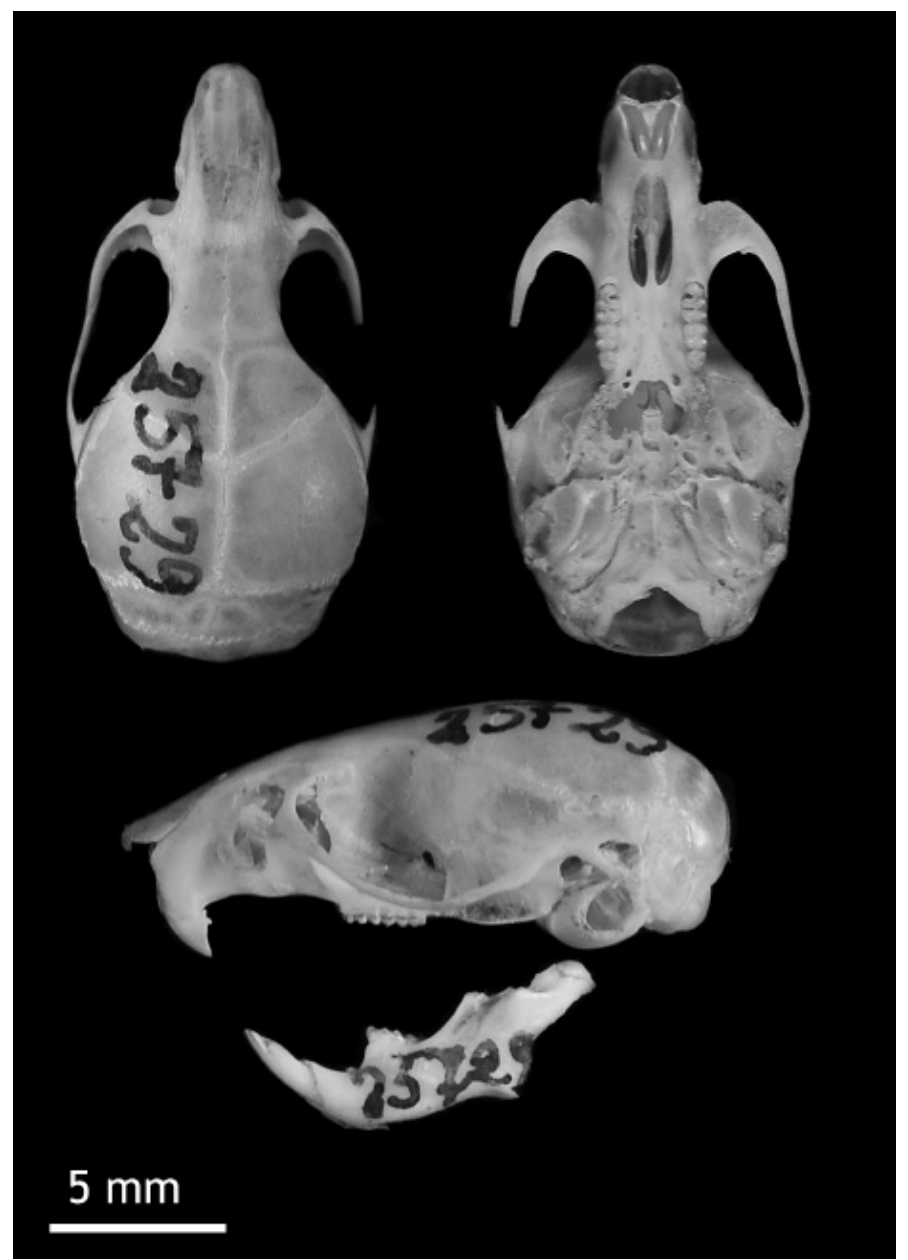

Figure 1. Dorsal, ventral, and lateral views of the skull, and lateral view of the mandibles of Calomys hummelincki (MZUSP 25729).

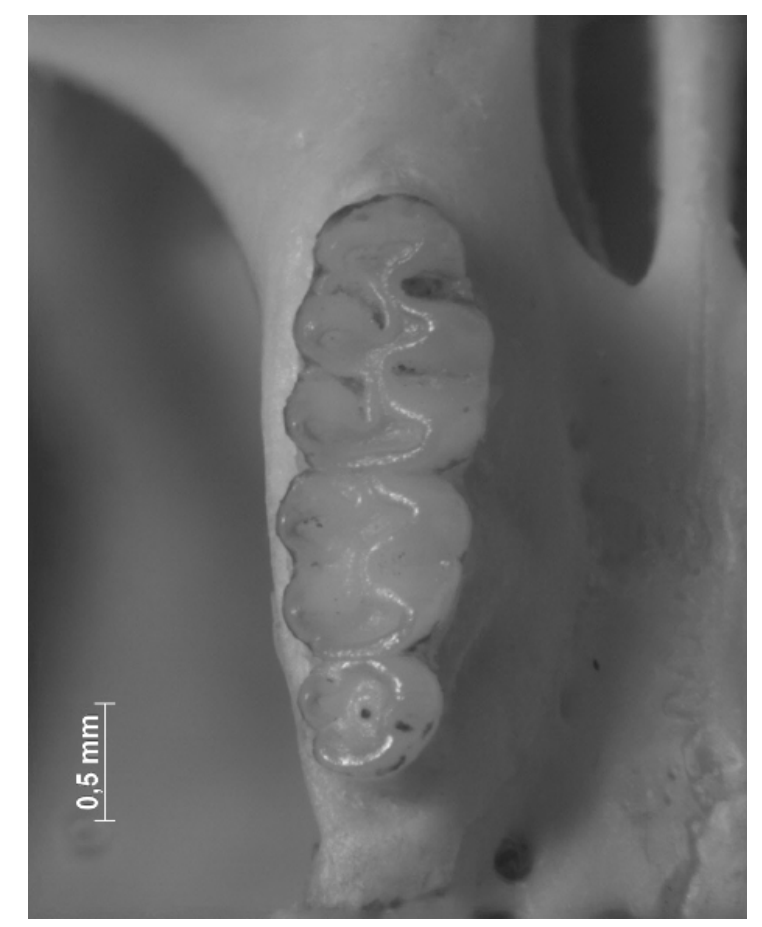

Figure 2. Right upper toothrow of Calomys hummelincki (MZUSP 25729).

separated by small elevations, locally known as "tesos". The ground cover is predominately grasses surrounding rocky outcrops. The vegetation is usually sparse, except on top of the "tesos" (Vanzolini and Carvalho 1991; Carvalho and Carvalho 2012). The climate in this region is characterized by a rainy season from April/May to August/September and a dry season from October to March. Average temperatures range between $22^{\circ}$ and $30^{\circ} \mathrm{C}$. Annual rainfall for 1989 was $1,884 \mathrm{~mm}$ (see Vanzolini and Carvalho 1991; Carvalho 1992).

\section{Results}

The new specimen is clearly a representative of the genus Calomys with body and skull measurements comparable only to those of $C$. laucha, C. tener and C. hummelincki (Table 1; see Bonvicino et al. 2010; Salazar-Bravo 2015). Moreover, based on the description in Salazar-Bravo (2015), MZUSP 25,729 exhibits all of the diagnostic external and craniodental characters of $C$. hummelincki, including grayish-orange dorsal pelage; mostly white ventral fur; distinct buffy post-auricular patches; weakly bicolored tail; short, narrow hind-feet covered with whitish hair; short and slender rostrum; shallow zygomatic notches; supraorbital region posteriorly divergent but not ridged; alisphenoid strut absent; greatest length of skull less than 21.0 $\mathrm{mm}$; molar toothrow less than $3.3 \mathrm{~mm}$ (Figure 1). Other craniodental measurements for MZUSP 25,729 (Table 1) fall within the range of variation for this species.

Importantly, however, MZUSP 25,729 differs from other specimens of $C$. hummelincki in some traits, including a shallow (or absent) anteromedian flexus on M1 (versus a deeply divided $\mathrm{M} 1$ in individuals of the type series); presence of an anteromedian style, a trait present in fewer than $10 \%$ of the specimens studied by Olds (1988); and a wider-than-average incisive foramen. Finally, MZUSP 25,729 has an upper molar series with molar proportions (M1:M2 and M2:M3) somewhat 
Table 1. External and cranial measurements (in millimetres) of Calomys hummelincki specimens. Data are given as: minimum and maximum (Range), mean $(\bar{X})$, standard deviation (SD), and sample size (n). *New specimen; "* from Bekker (1999).

\begin{tabular}{|c|c|c|c|c|c|c|c|}
\hline \multirow[t]{2}{*}{ Traits } & \multirow{2}{*}{$\begin{array}{c}\text { MZUSP 25729* } \\
+\end{array}$} & \multicolumn{2}{|c|}{$(n=4) * *$} & \multicolumn{2}{|c|}{$q(\boldsymbol{n}=\mathbf{3}) * *$} & \multicolumn{2}{|c|}{ Total $(n=8)^{* *}$} \\
\hline & & Range & $\overline{\mathbf{X}} \pm \mathrm{SD}$ & Range & $\overline{\mathbf{X}} \pm \mathrm{SD}$ & Range & $\overline{\mathbf{X}} \pm \mathrm{SD}$ \\
\hline Head and body & 55.0 & $57.0-67.0$ & $61.4 \pm 4.7$ & $55.0-63.0$ & $58.3 \pm 4.1$ & $55.0-67.0$ & $60.2 \pm 4.5$ \\
\hline Tail, without tuft & 59.0 & $45.0-54.0$ & $49.7 \pm 3.7$ & $45.0-51.0$ & $48.0 \pm 4.2$ & $45.0-54.0$ & $49.2 \pm 3.6$ \\
\hline Hind foot, without nail & 15.0 & $13.4-13.7$ & $13.5 \pm 0.1$ & $13.7-14.0$ & $12.8 \pm 0.2$ & $13.4-14.0$ & $13.7 \pm 0.2$ \\
\hline Ear, from notch & 8.0 & $10.1-11.7$ & $10.9 \pm 0.6$ & $10.3-11.2$ & $10.7 \pm 0.6$ & $10.1-11.7$ & $10.9 \pm 0.6$ \\
\hline Greatest skull length & 18.3 & - & - & - & - & - & - \\
\hline Condylobasal length & 16.6 & $16.2-18.9$ & $17.6 \pm 1.1$ & $16.8-17.8$ & $17.4 \pm 0.5$ & $16.2-18.9$ & $17.6 \pm 0.9$ \\
\hline Basal length & 14.9 & $15.2-16.7$ & $16.1 \pm 0.6$ & $15.5-16.4$ & $16.0 \pm 0.4$ & $15.2-16.7$ & $16.1 \pm 0.5$ \\
\hline Palatinal length & 8.6 & $9.0-10.3$ & $9.6 \pm 0.5$ & $9.6-9.8$ & $9.7 \pm 0.1$ & $9.0-10.3$ & $9.6 \pm 0.3$ \\
\hline Incisive foramen length & 3.6 & $3.8-4.7$ & $4.3 \pm 0.3$ & $4.1-4.3$ & $4.2 \pm 0.1$ & $3.8-4.7$ & $4.2 \pm 0.2$ \\
\hline Nasal length & 6.1 & $6.1-8.2$ & $7.3 \pm 0.8$ & $6.7-7.5$ & $7.1 \pm 0.4$ & $6.1-8.2$ & $7.2 \pm 0.6$ \\
\hline Diastema & 4.1 & $4.0-4.9$ & $4.5 \pm 0.3$ & $4.5-4.7$ & $4.6 \pm 0.1$ & $4.0-4.9$ & $4.5 \pm 0.2$ \\
\hline Zygomatic breadth & $(9.8)^{1}$ & $10.0-11.5$ & $10.8 \pm 0.6$ & $10.2-10.8$ & $10.5 \pm 0.3$ & $10.0-11.5$ & $10.7 \pm 0.5$ \\
\hline Interorbital width & 3.1 & $3.2-3.5$ & $3.3 \pm 0.1$ & $3.1-3.4$ & $3.2 \pm 0.1$ & $3.1-3.5$ & $3.3 \pm 0.1$ \\
\hline Upper molar row length & 2.7 & $2.8-3.0$ & $2.9 \pm 0.0$ & $2.9-3.0$ & $2.9 \pm 0.0$ & $2.8-3.0$ & $2.9 \pm 0.1$ \\
\hline Lower molar row length & 2.8 & $3.2-3.5$ & $3.3 \pm 0.1$ & $3.1-3.4$ & $3.2 \pm 0.1$ & $3.1-3.5$ & $3.3 \pm 0.1$ \\
\hline Mandible length & - & $9.3-10.3$ & $9.8 \pm 0.4$ & $9.5-10.0$ & $9.8 \pm 0.2$ & $9.3-10.3$ & $9.8 \pm 0.3$ \\
\hline
\end{tabular}

${ }^{1}$ Approximated measurement, right zygomatic arch broken (see Figure 1).

different from those in populations farther north. Of special note is the proportionally larger M3 (ca. $75 \%$ of M2) in the specimen from Roraima (Figure 2), when compared to C. hummelincki from other populations (ca. $70 \%$ of $\mathrm{M} 2$ ).

\section{Discussion and Conclusions}

The new record reported here extends the distribution of the species about $630 \mathrm{~km}$ SE from the nearest previous record (Sipao, Estado Bolívar, Venezuela; Figure 3). Although the range of $C$. hummelincki is still disjunct with respect to those

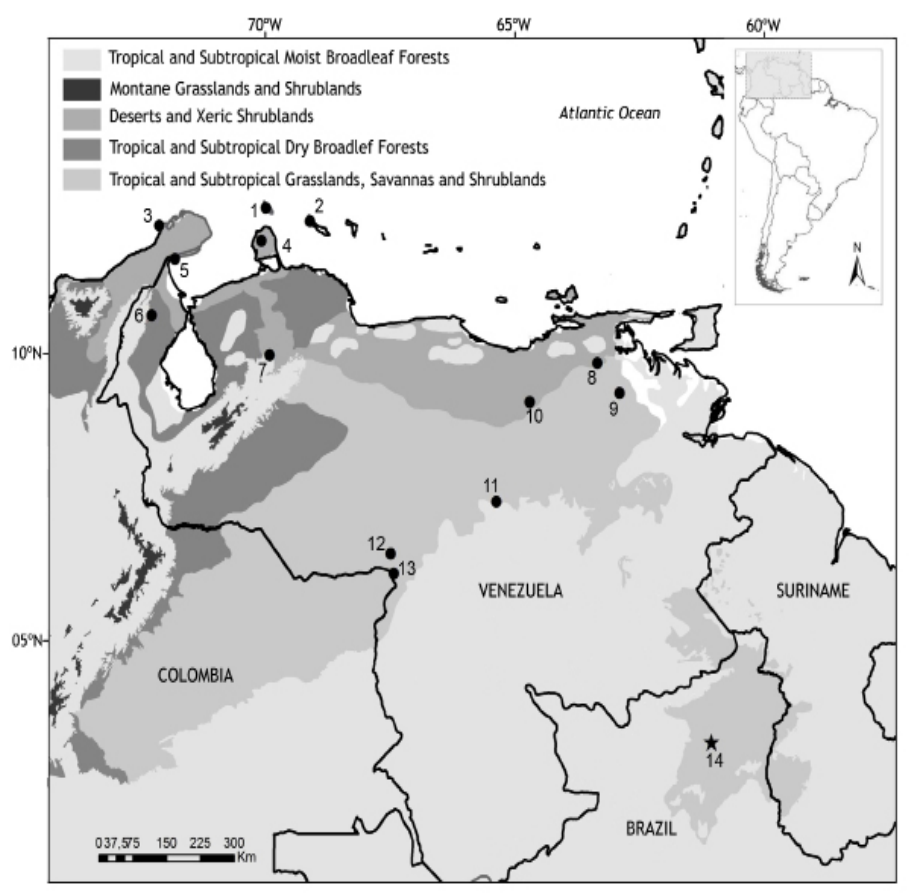

of other species of Calomys in South America, the new record considerably decreases the gap between them.

The current arrangement of vegetation communities north of the Amazon basin, where series of savannas are intermingled with forests, may be explained by the expansion and contraction of forest habitats during the Quaternary. The specific plant physiognomy dominating a particular area is influenced by a combination of soil, climate and elevation (Pennington et al. 2000; Vivo and Carmignotto 2004; Barbosa et al. 2007). We suggest that during drier periods, C. hummelincki expanded its distribution into northern South America along with the expansion of savanna vegetation formations. If, however, $C$. hummelincki evolved in the grasslands and savannas of northern South America, expanded distribution toward the south, offers a parsimonious biogeographic alternative. Either way, the population reported here is isolated from other populations of the species by a large tract of Tropical Moist Broadleaf Forest, no less than 130-km-wide, which separates the Gran Sabana/Rio Branco-Rupununi complex from the llanos. Nonetheless, future faunal assessments should be alert to the possible presence of $C$. hummelincki in the Ventuari and Esmeralda savannas of southern Venezuela.

Figure 3. Known records for Calomys hummelincki (modified from Salazar-Bravo 2015). The star represents the new record. Numbers in parentheses correspond to locality numbers on the map. Colombia: 1) Aruba, Sero Blanco, Colombia ( $\left.12^{\circ} 31^{\prime} \mathrm{N},-70^{\circ} 01^{\prime} \mathrm{W}\right)$; 2) Curaçao, Klein Santa Marta (12。 $\left.16^{\prime} 59^{\prime \prime} \mathrm{N},-69^{\circ} 07^{\prime} 59^{\prime \prime} \mathrm{W}\right)$; 3) Arroyo Cerrejón, Cabo de la Vela, La Guajira ( $\left.12^{\circ} 12^{\prime} 33^{\prime \prime} \mathrm{N},-72^{\circ} 08^{\prime} 51^{\prime \prime} \mathrm{W}\right)$. Venezuela 4) Falcón, Isiro (11 $56^{\prime} 57^{\prime \prime} \mathrm{N},-70^{\circ}$

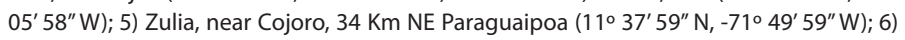

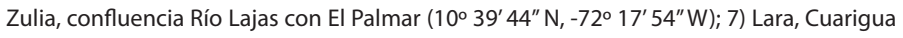

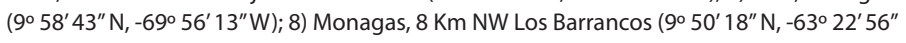

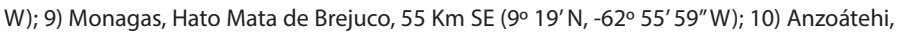

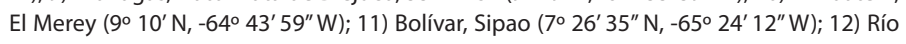
Cinaruco, 38 Km NW Puerto Paez (6॰ $\left.33^{\prime} \mathrm{N},-67^{\circ} 31^{\prime} \mathrm{W}\right)$; 13) pure, Puerto Paez (6॰ $12^{\prime} 27^{\prime \prime} \mathrm{N}$, $\left.-67^{\circ} 27^{\prime} 04^{\prime \prime} \mathrm{W}\right)$; Brazil: 14) Fazenda Salvamento, Roraima ( $3^{\circ} 20^{\prime} \mathrm{N},-61^{\circ} 24^{\prime} \mathrm{W}$ ). 
Although the Roraima savannas currently lack legally protected areas for the conservation of biodiversity, about $46 \%$ of the territory in this region is under the protection of the State as Indigenous land. With few exceptions (e. g., Barbosa et al. 2007), the mammal communities in the region are poorly known, especially as concerns small species such as marsupials, rodents, and bats. According to Voss (1991: table 30), only three out of nine non-forest mammals (Zygodontomys brevicauda, Calomys hummelincki, and Cavia aperea) occurring in northern South America are known from the Rio Branco-Rupununi savannas. Others, for example, Dasypus sabanicola and Lutreolina crassicaudata, are not known from the area, but are likely to occur there. This report, documenting the occurrence of C. hummelincki in this habitat, highlights the need to investigate and protect the biodiversity of the Rio Branco-Rupununi savannas. Further research on Calomys in this region is also needed to assess the genetic divergence of this isolated population.

\section{Acknowledgments}

We would like to thank MZUSP curator M. de Vivo and staff member J. G. de Barros for providing access to specimens under their care. William Lidicker and two anonymous reviewers made valuable comments that improved the quality of the manuscript.

\section{Literature cited}

Barbosa, R. I., C. Campos, F. Pinto, and P. M. Fearnside. 2007. The "Lavrados" of Roraima: biodiversity and conservation of Brazil's Amazonian Savannas. Functional Ecosystems and Communities 1:29-41.

BEKKER, J.P. 1999. The mammals of Aruba (Mammalia:Chiroptera, Rodentia, Lagomorpha). Vereniging voor Zoogdierkunde en Zoogdierbescherming. Utrecht, Netherlands.

Bonvicino, C. R., J. A. Oliveira, And R. Gentile. 2010. A new species of Calomys (Rodentia: Sigmodontinae) from southeastern Brazil. Zootaxa 2336:19-35.

Carvalmo, C. M. 1992. Estrategias reprodutivas de duas espécies simpátricas de lagartos do gênero Gymnophthalmus de Roraima, Brasil (Sauria, Teiidae). PhD Dissertation. Instituto Nacional de Pesquisas da Amazônia, Fundação Universidade do Amazonas.

Carvalho, C. M. 2002. Descrição de uma nova espécie de Micrurus do Estado de Roraima, Brasil (Serpentes, Elapidae). Papéis Avulsos de Zoologia 42:183-192.

Carvalho, T. M., and C. M. Carvalho. 2012. Interrelation of geomorphology and fauna of Lavrado region in Roraima, Brazil - suggestions for future studies. Quaternary Science Journal 61:146-158.

Gurgel-Filho, N. M., A. Feijó, and A. Langguth. 2015. Pequenos mamíferos do Ceará (marsupiais, morcegos e roedores sigmodontíneos) com discussão taxonômica de algumas espécies. Revista Nordestina de Biologia 23:3-150.

Martino, A. M. G., M. G. Filippuccl, And E. Capanna. 2002. Evolutive pattern of Calomys hummelincki (Husson1960; Rodentia, Sigmodontinae) inferred from cytogenetic and allozymic data. Mastozoología Neotropical 9:187-197.
OLDS, N. 1988. A revision of the genus Calomys (Rodentia: Muridae). PhD Dissertation. New York: City University of New York. New York, U. S. A.

Paglia, A.P., G. A. B., Fonseca, A. B. Rylands, G. Herrmann, L. M. S. Aguiar, AND A. G. Chiarello. 2012. Lista Anotada dos Mamíferos do Brasil. Occasional papers in conservation Biology. Conservation Internacional, Arlington, U. S. A.

Pennington, R. T., D. E. Prado, and C. A. Pendry. 2000. Neotropical seasonally dry forest and Quaternary vegetation changes. Journal of Biogeography 27:261-273.

Salazar-Bravo, J. 2015. Genus Calomys Waterhouse, 1837. Pp.481-507 in Mammals of South America, volume 2: Rodents (Patton, J. L., U. F. J. Pardiñas, and G. D'Elía, (eds.). The University of Chicago Press, Chicago and London. Chicago, U.S.A.

Vanzolini, P. E., and C. M de Carvalho. 1991. Two sibling and sympatric species of Gymnophtalmus in Roraima, Brasil (Sauria, Teiidae). Papéis Avulsos de Zoologia 37:173-226.

Vivo, M., AND A. P. CARmignotto. 2004. Holocene vegetation change and the mammal faunas of South America and Africa. Journal of Biogeography 31:943-957.

Voss, R. S. 1991. An introduction to the Neotropical muroid rodent genus Zygodontomys. Bulletin of the American Museum of Natural History 210:1-113.

Zeballos, H., R. E. Palma, P. A. Marquet, and G. Ceballos. 2014. Phylogenetic relationships of Calomys sorellus complex (Rodentia: Cricetidae), with the description of two new species. Revista Mexicana de Mastozoología (nueva época) $4: 1-23$.

Associated editor: William Lidicker

Submitted: October 18, 2016; Reviewed: November 25, 2016;

Accepted:December 15, 2016; Published on line: January 13, 2017. 